\title{
COMPARISON BETWEEN SOME CULTIVARS AND VARIETIES OF EGYPTIAN COTTON USING DIFFERENT ANALYSIS OF LATIN SQUARE DESIGN
}

(Received: 10. 10. 2011)

\author{
By \\ H. A. Idris \\ Cotton Research Institute, Agricultural Research Center, Giza, Egypt.
}

\begin{abstract}
The present investigation dealt with the comparison between cultivars and varieties for some Egyptian cotton (Gossypium barbadense L.) genotypes with respect to the production of yield (seed and lint) and its components in both the Delta and Upper Egypt during 2009 and 2010 seasons. The materials used in this study were two groups of long staple Egyptian cotton. One cultivar G86 and three varieties, viz. (G89 x G86), (G75 x Sea) and (10229 x G86) were evaluated in the Delta (Mounofia and Gharbia). Two cultivars G80 and G90 with two varieties, viz. (G83 x (G75 x 5844)) x G80 and G90 x Australian were evaluated in Upper Egypt (Minya and Beni Souf). Simple latin square design (4 x 4) was used in each location. Different analysis of latin square design were used to estimate the variance among genotypes. Analysis of simple was used to estimate the variance among the genotypes in the individual locations. 10229 x G.86 significantly surpassed G86 for yield, seed and lint indices in Mounofia and Gharbia. Non significant variations among genotypes were detected on yield and its components except for both seed and lint indices in Minya and Beni Souf. G80 significantly surpassed G90 x Australian for the two yield components and (G83 x (G75 x 5844)) x G80 in seed index. Insignificant differences among genotypes were recorded for fiber properties in Mounofia and Beni Souf. Analysis of traditional combined was used to estimate the variance among genotypes in both the Delta and Upper Egypt. 10229 x G.86 was the best variety in the Delta. It gave the highest values for yields (seed and lint), seed and lint indices, significantly surpassed G86. Insignificant variations among genotypes were detected on yield and its components except both seed and lint indices in Upper Egypt. (G83 x (G75 x 5844)) x G80 significantly surpassed cultivar G90 for lint index. Analysis of multiple was used to estimate the variance among genotypes in different zone. In this research the data of both the Delta and Upper Egypt (4 x 4) were used together to produce latin square design $(8 \times 8)$. Statistical analysis of multiple was similar to analysis of simple latin square design. A significant difference between cultivars vs. varieties was observed for seed and lint cotton yield. The analysis of variance showed that the variance among the varieties was bigger than among the cultivars for yield and its components except for boll weight which was slightly different. Multiple analysis can easily calculate the variance among genotypes were grown in different separated zones, such as the Delta and Upper Egypt in one step, while combined analysis can not do that. This study is important to regional cotton program.
\end{abstract}

Key words: cotton, Delta, genotypes, latin square design, locations, Upper Egypt, zone.

\section{INTRODUCTION}

Latin square design layout of the experiment was divided into homogenous blocks in two ways. The blocks in one direction are commonly known as rows and the blocks in perpendicular direction as columns. The number of plots in each row is the same as the number of plots in each column. This number is equal to the number of treatments, (Sing and Narayanan, 2000). A version of ANOVA known as the latin square design enables the partitioning of sum of squares due to observations of treatments, that is the main effect the observer is interested in, and the sums of squares attributable to each of the gradients. The design is especially suitable for investigating the effects of different treatments such as fertilizers, management techniques, etc. One some variable that can be measured in quadrates placed one the ground. The quadrate grid has an equal number of columns and rows representing the number of different treatments and constructed so that a particular treatment occurs once only in each row and column, (Fowler et al., 1998)

Abou Tour et al. ( 1996 ) evaluated 10 long 
staple Egyptian cotton cultivars. Five of them viz., G75, G81, G85, G86 and G89 were evaluated in three locations in the Delta. The five viz., G85, G83, G80, Dandara and G75 were evaluated in the three locations in Upper Egypt. They used latin square design in each location. The results of combined analysis revealed that significant differences among cultivars were observed with respect to lint cotton yield in both the Delta and Upper Egypt.

El Oraby (1998) evaluated 5 long Egyptian cotton genotypes, viz. G.75, G.85, G.80, G.83 and G.89 in the Delta and Upper Egypt. The results of combined analysis showed that mean squares of genotypes with respect to boll weight and seed index differed significantly.

Idris (2006) evaluated five Egyptian cotton genotypes in two locations in Upper Egypt. Three of them were cultivars, viz., G80, G83 and G90, while the other genotypes were varieties viz., (G81 $x$ G83) and G83 (G75 x 5844). Latin square design was used in each location. The results of individual locations revealed that significant differences between cultivars and varieties were observed with respect to yield (seed and lint).

Idris and Abou Tour (2007) evaluated two gropes of cotton. The first, viz. G85, G86, G89 and G89 x G86 were evaluated in the Delta (Monofia and Gharbia). The second group, viz. G80, G83, G90 and G91 were evaluated in Upper Egypt (Assuit and Beni Souf). Randomized complete block design was used in each experiment. The final goal was to study the possibility of useing a modified analysis of randomized complete block design to replace the use of traditional combined analysis. The results showed that the modified analysis could estimate two groups of genotypes variance on one stage of analysis, while combined analysis gave the same variance using two stages of analysis.

Idris (2008) evaluated five Egyptian cotton genotypes, viz., G85, G86, G89, (G89 x G86) and (G89 x Pima S-6) in two locations in the Delta using latin square design. The results showed that variety G89 x Pima S-6 was the best genotype for yields (seed and lint) since it kept the first number in the first pick in the two locations and indicating that the maturity of this variety was faster than other genotypes. Cultivar G86 was the best variety with respect to fiber length in the two picks in the two locations.

Arafa and Nour (2011) evaluated two Egyptian cotton cultivars G80 and 90 with one variety (G83 x (G75 x 5844)) x G80 with respect to fiber properties in four locations in Upper
Egypt. The results of average in four locations showed that the differences between them were slightly with respect to fiber length and micronaire reading. On contrast, the difference between them was noticed for strength.

Researchers need a statistical measure to evaluate cultivars and varieties grown under different zones. Thus, the objective of the present study was to estimate the variance among genotypes in different zones using different analysis of latin square design.

\section{MATERIALS AND METHODS}

The materials used in this study were two groups of long staple Egyptian cotton (Gossypium barbadense L.) genotypes. One field experiment (4 x 4) simple latin square design was carried out in two different locations in the Delta (Mounofia and Gharbia) during 2009 and 2010 seasons, respectively. The materials used in these experiments were one cultivar G86 and three varieties (Bulk families), viz. (G89 x G86), (G75 x Sea) and (10229 x G86). On the other hand, the same design was carried out in two different locations in the Upper Egypt (Minya and Beni Souf) in 2009 and 2010 seasons, respectively. The materials used in these locations were two cultivars G80 and G90 and two varieties (Bulk families), viz. (G83 x (G75 x 5844)) x G80 and G90 x Australian.

Genotypes in the Delta and Upper Egypt were evaluated for the production of yields (seed (S.Y) and lint (L.Y)) in kentar/ feddan, its components and fiber properties. One sample (50 bolls) was obtained from each plot in all locations to estimate yield components viz., boll weight (B.W.) in g, number of seeds per boll (S / B), seed index (S.I) in $\mathrm{g}$ and lint index (L.I) in g. One sample (lint) was obtained from each plot in one location in the Delta (Mounofia) and Upper Egypt (Beni Souf) to estimate fiber properties in different zones viz., fiber length (F.L.), micronaire reading (Mic) and pressely index (P.I). The lint cotton samples were tested in the Cotton Research Laboratories, Cotton Research Institute.

\subsection{Statistical analysis}

\subsubsection{Analysis of simple latin square design}

The traditional simple analysis was carried out with the data of the four governorates to estimate the variance among genotypes in individual locations in the Delta and Upper Egypt (Table 1). Thus, statistical analysis of simple latin square design was performed according to a single determination per plot (Table 3).

\subsubsection{Analysis of combined latin square design}


The traditional combined analysis was carried out with the data of two governorates in the Delta and Upper Egypt to estimate the variance among 21 genotypes. (Table 3 ).

\subsubsection{Analysis of multiple latin square design}

A multiple analysis suggested by the author was used to estimate the variance among the genotypes in different zones. In this paper the data of the Delta and Upper Egypt (4 x 4) were used together to produce latin square design $(8 \times 8)$. The number of plots in each row is the same as the number of plots in each column. This number is equal to the number of treatments. Each treatment occurs the same number of times (usually once) in each row and column (Table 2). Thus, statistical analysis of multiple latin square design was similar to the analysis of simple latin square design with a single determination per plot (Table3). The objective of multiple analysis was to estimate the variance among the genotypes in different zones (Delta and Upper Egypt) and partitioning them to compare between cultivars and varieties. The second objective was developing simple latin square to use a combined analysis.

Statistical analysis of simple, combined and multiple latin square designs were straightforward according to Cochran and Cox (1950), Federer (1955), Little and Hills (1978), Gomez and Gomez (1984), Roger (1994), Fowler et al. (1998) and Mcpherson (2001). The treatment means were compared by L.S.D. test as given by Steel and Torrie (1980). All comparisons were done at 0.05 level of significance. Homogeneity test of variances (Bartlett test) was used according to the procedures reported by Bailey (1994):

$$
\begin{aligned}
& X^{2}=\frac{1}{C}\left[f_{t} \ln s_{p}^{2}-\sum_{i} f_{i} \ln s_{i}^{2}\right] \text { for } k-1 \quad d . f . \\
& \text { where } C=1+\frac{1}{3(k-1)}\left(\sum_{i} \frac{1}{f_{i}}-\frac{1}{f_{t}}\right) \quad(\text { as } C . F .) \\
& \quad S_{P}^{2}=\sum_{i}\left(f_{i} S_{i}^{2}\right) / f_{t} \\
& f_{i}: \text { d.f. associated with each } S^{2} i(\text { or m. s. }) \\
& K: \text { no. } S^{2} i(\text { or m. s. }) \text { being compared. } \\
& f_{t}: \text { total d.f. }
\end{aligned}
$$

\section{RESULTS AND DISCUSSION 3.1.Analysis of simple latin square design}

The analysis of variance in individual locations using simple analysis with respect to yield and its components revealed the presence of significant differences among genotypes in each location in the Delta and Upper Egypt (Table 4).

\subsubsection{Delta}

Significant differences among the genotypes were observed for yield and its components except for boll weight in Mounofia (Table 4). The results presented in (Table 4) showed that variety 10229 x G.86 was the best in this location since it gave the highest values for yields (seed and lint), seed and lint index, significantly surpassed G86. Variety G75 x Sea exhibited similar results for seed cotton yield and seed per boll, it significantly exceeded G86. On contrast, cultivar G86 significantly surpassed variety G75 x Sea for lint index. Non significant variations among genotypes were recorded for fiber properties, which explain that all genotypes were within the long staple group (Table 6).

Significant variations among genotypes were observed for yield and its components except for seeds per boll in Gharbia (Table 4). Variety 10229 x G.86 gave the same results in Gharbia. Variety G75 x Sea significantly exceeded G86 for seed cotton yield. On contrast, G86 significantly surpassed both G89 x G86 and G75 x Sea for yield components, viz. boll weight, seed index and lint index (Table 5).

These results exhibited that the difference between G75 x Sea and G86 was significant for seed cotton yield, while the difference was insignificant for lint cotton yield in both Mounofia and Gharbia due to decreased lint percentage for variety than cultivar.

\subsubsection{Upper Egypt}

The results showed that in the two locations insignificant variations among genotypes were detected on yield and its components except for both seed and lint indices indicating that the behavior of genotypes was similar in Minya and Beni Souf except for two yield components (Table 4).

Cultivar G80 was the best genotype in the two locations since it gave the highest values for seed and lint indices, it significantly surpassed variety G90 x Australian for the two yield components and variety (G83 x (G75 x 5844)) x G80 with respect to seed index (Table 5).

Non significant differences among genotypes were noticed for fiber properties in Beni Souf, which explain that all genotypes were long staple group (Table 6). 
Table (1) Layout for simple latin square design in four locations.

\begin{tabular}{|c|c|c|c|}
\hline $\mathbf{V}_{\mathbf{2}}$ & $\mathbf{A}$ & $\mathbf{V}_{\mathbf{1}}$ & $\mathbf{V}_{\mathbf{3}}$ \\
\hline $\mathbf{V}_{\mathbf{1}}$ & $\mathbf{V}_{\mathbf{3}}$ & $\mathbf{V}_{\mathbf{2}}$ & $\mathbf{A}$ \\
\hline $\mathbf{A}$ & $\mathbf{V}_{\mathbf{2}}$ & $\mathbf{V}_{\mathbf{3}}$ & $\mathbf{V}_{\mathbf{1}}$ \\
\hline $\mathbf{V}_{\mathbf{3}}$ & $\mathbf{V}_{\mathbf{1}}$ & $\mathbf{A}$ & $\mathbf{V}_{\mathbf{2}}$ \\
\hline
\end{tabular}

Mounofia 2009 season (Delta)

\begin{tabular}{|c|c|c|c|}
\hline $\mathbf{V}_{5}$ & $\mathbf{B}$ & $\mathbf{C}$ & $\mathbf{V}_{4}$ \\
\hline $\mathbf{C}$ & $\mathbf{V}_{\mathbf{4}}$ & $\mathbf{B}$ & $\mathbf{V}_{\mathbf{5}}$ \\
\hline $\mathbf{B}$ & $\mathbf{V}_{5}$ & $\mathbf{V}_{4}$ & $\mathbf{C}$ \\
\hline $\mathbf{V}_{4}$ & $\mathbf{C}$ & $\mathbf{V}_{5}$ & $\mathbf{B}$ \\
\hline
\end{tabular}

Beni Souf 2010 season (Upper Egypt)

\begin{tabular}{|c|c|c|c|}
\hline $\mathbf{V}_{5}$ & $\mathbf{B}$ & $\mathbf{C}$ & $\mathbf{V}_{4}$ \\
\hline $\mathrm{C}$ & $\mathrm{V}_{4}$ & $\mathbf{B}$ & $\mathbf{V}_{5}$ \\
\hline $\mathbf{B}$ & $\mathrm{V}_{5}$ & $\mathbf{V}_{4}$ & $\mathbf{C}$ \\
\hline $\mathrm{V}_{4}$ & $\mathrm{C}$ & $\mathrm{V}_{5}$ & $\mathrm{~B}$ \\
\hline
\end{tabular}

Minya 2009 season (Upper Egypt)

\begin{tabular}{|c|c|c|c|}
\hline $\mathbf{V}_{\mathbf{2}}$ & $\mathbf{A}$ & $\mathbf{V}_{\mathbf{1}}$ & $\mathbf{V}_{\mathbf{3}}$ \\
\hline $\mathbf{V}_{\mathbf{1}}$ & $\mathbf{V}_{\mathbf{3}}$ & $\mathbf{V}_{\mathbf{2}}$ & $\mathbf{A}$ \\
\hline $\mathbf{A}$ & $\mathbf{V}_{\mathbf{2}}$ & $\mathbf{V}_{\mathbf{3}}$ & $\mathbf{V}_{\mathbf{1}}$ \\
\hline $\mathbf{V}_{\mathbf{3}}$ & $\mathbf{V}_{\mathbf{1}}$ & $\mathbf{A}$ & $\mathbf{V}_{\mathbf{2}}$ \\
\hline
\end{tabular}

Gharbia 2010 season (Delta)
$A=G 86 \quad V_{1}=$ G89 $\times$ G86
$\mathrm{V}_{2}=\mathbf{G 7 5} \times$ Sea
$V_{3}=10229 \times$ G86
$\mathrm{B}=\mathrm{G80} \quad \mathrm{C}=\mathrm{G90}$
$V_{4}=(G 83 \times(G 75 \times 5844)) \times G 80$
$V_{5}=G 90 \times$ Australian

Table (2): Layout of multiple latin square design.

\begin{tabular}{|c|c|c|c|c|c|c|c|}
\hline$V_{2}$ & $A$ & $V_{1}$ & $V_{3}$ & $V_{5}$ & $B$ & $C$ & $V_{4}$ \\
\hline$V_{1}$ & $V_{3}$ & $V_{2}$ & $A$ & $C$ & $V_{4}$ & $B$ & $V_{5}$ \\
\hline$A$ & $V_{2}$ & $V_{3}$ & $V_{1}$ & $B$ & $V_{5}$ & $V_{4}$ & $C$ \\
\hline$V_{3}$ & $V_{1}$ & $A$ & $V_{2}$ & $V_{4}$ & $C$ & $V_{5}$ & $B$ \\
\hline$V_{5}$ & $B$ & $C$ & $V_{4}$ & $V_{2}$ & $A$ & $V_{1}$ & $V_{3}$ \\
\hline$C$ & $V_{4}$ & $B$ & $V_{5}$ & $V_{1}$ & $V_{3}$ & $V_{2}$ & $A$ \\
\hline$B$ & $V_{5}$ & $V_{4}$ & $C$ & $A$ & $V_{2}$ & $V_{3}$ & $V_{1}$ \\
\hline$V_{4}$ & $C$ & $V_{5}$ & B & $V_{3}$ & $V_{1}$ & $A$ & $V_{2}$ \\
\hline $\begin{array}{l}\text { A = G86 } \\
\text { B = G80 }\end{array}$
\end{tabular}

Table (3) : Different analyses of latin square design.

\begin{tabular}{|c|c|c|c|}
\hline \multicolumn{2}{|c|}{ Simple and multiple latin square } & \multicolumn{2}{|c|}{ Combined latin square } \\
\hline Source of variation & df & Source of variation & df \\
\hline & & Locations & L -1 \\
\hline Columns & k-1 & Columns within locations & L (k-1) \\
\hline Rows & k-1 & Rows within locations & L (k-1) \\
\hline Genotypes & k-1 & Genotypes within locations & L (k-1) \\
\hline & & Genotypes & k-1 \\
\hline & & Genotypes $x$ locations & $(\mathrm{k}-1)(\mathrm{L}-1)$ \\
\hline Experimental error & $(k-1)(k-2)$ & Experimental error & L (k-1) (k-2) \\
\hline Total & $k^{2}-1$ & Total & $L\left(k^{2}-1\right)$ \\
\hline
\end{tabular}


Table (4): Mean squares of yield and its components for simple latin (individual locations).

\begin{tabular}{|c|c|c|c|c|c|c|c|}
\hline \multicolumn{8}{|c|}{ Delta } \\
\hline \multirow[b]{2}{*}{ Source of variation } & \multirow[b]{2}{*}{ df } & \multicolumn{2}{|c|}{ Seed yield (k/fed.) } & \multicolumn{2}{|c|}{ Lint yield (k/fed.) } & \multicolumn{2}{|c|}{ Boll weight (g) } \\
\hline & & Mounofia & Gharbia & Mounofia & Gharbia & Mounofia & Gharbia \\
\hline Columns & 3 & 0.530 & $4.74 * *$ & 1.08 & $6.78^{* * *}$ & 0.003 & 0.007 \\
\hline Rows & 3 & 1.31 & $4.10 * *$ & 1.99 & $6.64 * *$ & 0.017 & 0.040 \\
\hline Genotypes & 3 & $2.54 *$ & $2.36 * *$ & 5.50* & $6.68 * *$ & 0.055 & $0.238 * *$ \\
\hline Experimental error & 6 & 0.341 & 0.220 & 0.625 & 0.558 & 0.022 & 0.017 \\
\hline Source of variation & df & \multicolumn{2}{|c|}{ Seeds per boll } & \multicolumn{2}{|c|}{ Seed index $(g)$} & \multicolumn{2}{|c|}{ Lint index. (g) } \\
\hline Columns & 3 & 0.715 & 0.826 & $0.354 *$ & $0.326^{*}$ & 0.019 & 0.049 \\
\hline Rows & 3 & 0.811 & 1.24 & 0.019 & 0.071 & 0.066 & 0.051 \\
\hline Genotypes & 3 & 4.74* & 2.51 & $1.14 * *$ & $2.15 * *$ & $1.62 * *$ & $3.72 * *$ \\
\hline Experimental error & 6 & 0.668 & 0.721 & 0.061 & 0.058 & 0.053 & 0.018 \\
\hline \multicolumn{8}{|c|}{ Upper Egypt } \\
\hline & & \multicolumn{2}{|c|}{ Seed yield (k/fed.) } & \multicolumn{2}{|c|}{ Lint yield (k/fed.) } & \multicolumn{2}{|c|}{ Boll weight (g) } \\
\hline Source of variation & df & Minya & Beni Souf & Minya & Beni Souf & Minya & Beni Souf \\
\hline Columns & 3 & 0.738 & 1.86 & 0.941 & 3.46 & 0.002 & 0.135 \\
\hline Rows & 3 & 1.68 & 2.54* & 2.63 & 3.76 & 0.030 & 0.038 \\
\hline Genotypes & 3 & 3.07 & 0.243 & 4.64 & 0.564 & 0.113 & 0.088 \\
\hline Experimental error & 6 & 0.955 & 0.438 & 1.73 & 0.934 & 0.067 & 0.060 \\
\hline Source of variation & df & \multicolumn{2}{|c|}{ Seeds per boll } & \multicolumn{2}{|c|}{ Seed index $(\mathrm{g})$} & \multicolumn{2}{|c|}{ Lint index. (g) } \\
\hline Columns & 3 & 0.073 & 4.84 & 0.054 & 0.212 & 0.008 & 0.207 \\
\hline Rows & 3 & 0.648 & 1.42 & 0.027 & 0.192 & 0.068 & 0.087 \\
\hline Genotypes & 3 & 5.53 & 2.23 & $3.04 * *$ & $0.832 * *$ & $0.668 *$ & $0.694 *$ \\
\hline Experimental error & 6 & 1.40 & 2.22 & 0.166 & 0.061 & 0.105 & 0.074 \\
\hline
\end{tabular}

* , ** Significant at 0.05 and 0.01 levels, respectively.

Table (5): Means of yield and its components for simple latin (individual locations).

\begin{tabular}{|c|c|c|c|c|c|c|}
\hline \multicolumn{7}{|c|}{ Delta } \\
\hline \multirow[b]{2}{*}{ Genotypes } & \multicolumn{2}{|c|}{ Seed yield (k/fed.) } & \multicolumn{2}{|c|}{ Lint yield (k/fed.) } & \multicolumn{2}{|c|}{ Boll weight (g) } \\
\hline & Mounofia & Gharbia & Mounofia & Gharbia & Mounofia & Gharbia \\
\hline G86 & 11.18 & 10.54 & 14.11 & 13.35 & 3.20 & 3.01 \\
\hline G89 x G86 & 11.40 & 10.60 & 13.93 & 13.16 & 3.16 & 2.49 \\
\hline G75 x Sea & 12.25 & 11.53 & 14.60 & 13.78 & 3.36 & 2.69 \\
\hline 10229 x G86 & 12.91 & 12.00 & 16.49 & 15.96 & 3.39 & 2.96 \\
\hline L.S.D. & 1.01 & 0.81 & 1.37 & 1.29 & -- & 0.23 \\
\hline Genotypes & \multicolumn{2}{|c|}{ Seeds per boll } & \multicolumn{2}{|c|}{ Seed index $(\mathrm{g})$} & \multicolumn{2}{|c|}{ Lint index. (g) } \\
\hline G86 & 18.55 & 17.30 & 10.32 & 10.40 & 6.93 & 7.00 \\
\hline G89 x G86 & 18.10 & 16.23 & 10.68 & 9.32 & 6.82 & 6.05 \\
\hline G75 x Sea & 20.07 & 16.92 & 10.42 & 9.90 & 6.33 & 6.05 \\
\hline 10229 x G86 & 17.53 & 15.51 & 11.50 & 11.05 & 7.85 & 8.07 \\
\hline L.S.D. & 1.42 & -- & 0.43 & 0.42 & 0.40 & 0.23 \\
\hline \multicolumn{7}{|c|}{ Upper Egypt } \\
\hline & \multicolumn{2}{|c|}{ Seed yield (k/fed.) } & \multicolumn{2}{|c|}{ Lint yield (k/fed.) } & \multicolumn{2}{|c|}{ Boll weight (g) } \\
\hline Genotypes & Minya & Beni Souf & Minya & Beni Souf & Minya & Beni Souf \\
\hline G80 & 10.05 & $\mathbf{8 . 8 8}$ & 12.46 & 11.57 & 3.02 & 2.84 \\
\hline G90 & 9.73 & 8.91 & 11.69 & 11.21 & 2.62 & 2.81 \\
\hline$(G 83 \times(G 75 \times 5844)) \times$ x 880 & 11.37 & 9.21 & 14.07 & 12.01 & 2.80 & 2.57 \\
\hline G90 x Australian & 9.35 & 9.39 & 11.91 & 11.97 & 2.73 & 2.56 \\
\hline L.S.D. & & -- & & -- & & \\
\hline Genotypes & \multicolumn{2}{|c|}{ Seeds per boll } & \multicolumn{2}{|c|}{ Seed index (g) } & \multicolumn{2}{|c|}{ Lint index. (g) } \\
\hline G80 & 16.66 & 17.66 & 11.00 & 9.43 & 7.15 & 6.68 \\
\hline G90 & 15.09 & 18.49 & 10.70 & 9.15 & 6.68 & 6.05 \\
\hline$(G 83 \times(G 75 \times 5844)) \times$ G80 & 15.91 & 16.79 & 10.85 & 8.98 & 6.85 & 6.35 \\
\hline G90 x Australian & 17.85 & 18.20 & 9.12 & 8.35 & 6.18 & 5.70 \\
\hline L.S.D. & -- & -- & 0.71 & 0.43 & 0.56 & 0.47 \\
\hline
\end{tabular}

--: Not significant at 0.05 level. 


\subsection{Analysis of combined latin square design}

The result of homogeneity of variance test (Bartlett test) was not significant for yield and its components in both the Delta and Upper Egypt. The results of analysis of variance among genotypes in the Delta were bigger than in the Upper Egypt for yield and its components except for seed index indicating that variation of genetic differences among group i.e., the Delta bigger than in Upper Egypt. On the other hand, experimental error in Upper Egypt was bigger than in Delta for yield and its components (Table 8).

\subsubsection{Delta}

Significant differences among genotypes were observed for yield and its components (Table 8). The results showed that variety 10229 x G.86 was the best one, it gave the highest values for yields (seed and lint), seed and lint indices significantly surpassed cultivar G86. Variety G75 x Sea had similar results with respect to seed cotton yield, it significantly exceeded G86. On contrast, cultivar G86 significantly surpassed varieties 10229 x G.86 for seeds per boll, G75 x Sea for lint index and G89 x G86 for boll weight, seed and lint index (Table 9).

\subsubsection{Upper Egypt}

The results showed that non-significant variations among genotypes were detected on yield and its components except for both seed and lint

Indices (Table 8). The results of comparison among genotypes exhibited that variety (G83 x (G75 x 5844)) x G80 significantly surpassed cultivar G90 for lint index. On contrast, the two cultivars G80 and G90 significantly exceeded variety G90 x Australian for both seed and lint indices (Table 9).

\section{3. Analysis of multiple latin square design}

A multiple analysis suggested by the author was used to estimate the variance among genotypes in different zones (Table 2). In this proposal the data of the Delta and Upper Egypt (4 $x$ 4) were used together to produce latin square design $(8 \times 8)$. Statistical analysis of multiple latin square design was similar to the analysis of simple latin square design with a single determination per plot.

The first objective of multiple analysis was to estimate the variance among genotypes in different zones. In addition, partitioning of genotype variance into cultivars, varieties and cultivars vs. varieties exhibited the variance for each part.

The second objective was developing simple latin square to use a combined analysis.

Significant differences among genotypes were observed for yield and its components (Table 10). The results showed that variety 10229 x G.86 was the best genotype within the two groups. It gave the highest values for yield (seed and lint) and yield components except for seeds per boll. It did not significantly differ from cultivar G86 for boll weight and variety G75 x Sea for seed cotton yield and boll weight, significantly surpassed all other genotypes. Variety G75 x Sea had the highest value for seeds per boll, it did not significantly differ from cultivar G86 and variety G90 x Australian, significantly exceeded other genotypes (Table 11).

Significant differences among cultivars were recorded for yield and its components except for seeds per boll and seed index (Table 10). The results exhibited that cultivar G86 was the best within the two groups with respect to yield (seed and lint). It kept the first rank significantly and surpassed the other two cultivars G80 and G90. In addition, the same cultivar had similar results for two yield components, it did not differ from G80, significantly exceeded G90 for boll weight and lint index. These results showed that this cultivar grown within the Delta surpassed two cultivars grown within Upper Egypt with respect to production of yield (seed and lint) indicating different levels of production between the two groups (Table 11).

Significant differences among varieties were detected for yield and its components (Table 10). The results showed that variety 10229 x G.86 was the best within the two groups, it gave the highest values for yield (seed and lint) and yield components except for seeds per boll. It did not significantly differ from G75 x Sea for seed cotton yield and boll weight, significantly surpassed all other varieties. Variety G75 x Sea had the highest value for seeds per boll, it did not significantly differ from G90 x Australian, significantly exceeded all other varieties (Table 11).

A significant difference between cultivars vs. varieties was observed for seed and lint cotton yield. The results showed that the production of yield did not depend on yield components due to the differences were non-significant (Table 10). The difference of production of yield between cultivars vs. varieties may be due to the different number of boll per plant, morphology of plant and genetic differences between both cultivars and varieties. This result was very important for the estimation of level of production between cultivars and new varieties. In addition, the results 
Table (6): Mean squares of fiber properties in the different zones (simple latin).

\begin{tabular}{|c|c|c|c|c|c|c|c|}
\hline \multirow[b]{2}{*}{ Source of variation } & \multirow[b]{2}{*}{ df } & \multicolumn{3}{|c|}{ Delta (Mounofia) } & \multicolumn{3}{|c|}{ Upper Egypt (Beni Souf) } \\
\hline & & F. L. (mm) & Mic. & P. I. & F. L. (mm) & Mic. & P. I. \\
\hline Columns & 3 & 1.12 & 0.146 & 0.066 & 0.267 & 0.040 & 2.30 \\
\hline Rows & 3 & 0.285 & $0.261 *$ & 0.252 & 0.029 & 0.012 & 0.248 \\
\hline Genotypes & 3 & 1.60 & 0.111 & 0.191 & 0.536 & 0.007 & 0.445 \\
\hline Experimental error & 6 & 0.749 & 0.042 & 0.064 & 0.346 & 0.019 & 0.521 \\
\hline Total & 15 & & & & & & \\
\hline
\end{tabular}

*, ** Significant at 0.05 and 0.01 levels, respectively.

Table (7): Means of fiber properties in the different zones (simple latin).

\begin{tabular}{|c|c|c|c|c|c|c|}
\hline \multirow[b]{2}{*}{ Genotypes } & \multicolumn{3}{|c|}{ Delta (Mounofia) } & \multicolumn{3}{|c|}{ Upper Egypt (Beni Souf) } \\
\hline & F. L. (mm) & Mic. & P. I. & F. L. (mm) & Mic. & P. I. \\
\hline G86 & 33.25 & 4.05 & 10.60 & & & \\
\hline G89 x G86 & 33.43 & 4.43 & 10.30 & & & \\
\hline G75 x Sea & 34.53 & 4.13 & 10.58 & & & \\
\hline 10229 x G86 & 34.30 & 4.13 & 10.15 & & & \\
\hline L.S.D. & -- & -- & -- & & & \\
\hline G80 & & & & 33.98 & 4.23 & 9.95 \\
\hline G90 & & & & 33.38 & 4.23 & 9.95 \\
\hline$(G 83 \times(G 75 \times 5844)) \times G 80$ & & & & 33.53 & 4.18 & 10.62 \\
\hline G90 x Australian & & & & 33.10 & 4.28 & 9.98 \\
\hline L.S.D. & & & & -- & -- & -- \\
\hline
\end{tabular}

--: Not significant at 0.05 level.

Table (8): Mean squares of yield and its components for combined latin square.

\begin{tabular}{|c|c|c|c|c|c|c|c|}
\hline \multicolumn{8}{|c|}{ Delta } \\
\hline Source of variation & df & $\begin{array}{c}\text { S. Y. } \\
\text { (k/fed.) }\end{array}$ & $\begin{array}{l}\text { L. Y. } \\
\text { (k/fed.) }\end{array}$ & $\begin{array}{c}\text { B. W. } \\
\text { (g) }\end{array}$ & S / B & $\begin{array}{r}\text { S. I. } \\
(\mathrm{g})\end{array}$ & $\begin{array}{r}\text { L. I. } \\
\text { (g) }\end{array}$ \\
\hline Locations (L) & 1 & $4.71 * *$ & $4.16 *$ & $1.93 * *$ & $34.41 * *$ & $2.53 * *$ & $0.286^{*}$ \\
\hline Columns within (L) & 6 & $2.64 * *$ & $3.89 * *$ & 0.005 & 0.770 & $0.340 * *$ & 0.035 \\
\hline Rows within $(\mathbf{L})$ & 6 & $2.71 * *$ & 4.31** & 0.028 & 1.03 & 0.045 & 0.058 \\
\hline Genotypes within (L) & & $2.45 * *$ & $6.09 * *$ & $0.147 * *$ & $3.63 * *$ & $1.65 * *$ & $2.67 * *$ \\
\hline Genotypes (G) & 3 & $4.89 * *$ & $12.14 * *$ & $0.186 * *$ & $6.00 * *$ & $2.60 * *$ & $4.95 * *$ \\
\hline G X L & 3 & 0.013 & $\mathbf{0 . 0 3 3}$ & 0.107* & 1.25 & $0.693^{* * *}$ & $0.390 * *$ \\
\hline Experimental error & 12 & 0.280 & 0.592 & 0.019 & 0.694 & 0.059 & 0.036 \\
\hline Total & 31 & & & & & & \\
\hline \multicolumn{8}{|c|}{ Upper Egypt } \\
\hline Source of variation & df & $\begin{array}{c}\text { S. Y. } \\
\text { (k/fed.) }\end{array}$ & $\begin{array}{c}\text { L. Y. } \\
\text { (k/fed.) }\end{array}$ & $\begin{array}{c}\text { B. W. } \\
(\mathrm{g})\end{array}$ & S / B & $\begin{array}{r}\text { S. I. } \\
\text { (g) }\end{array}$ & $\begin{array}{c}\text { L. I. } \\
\text { (g) }\end{array}$ \\
\hline Locations (L) & 1 & $8.43 * *$ & 5.63 & 0.078 & 15.96* & $16.68^{* * *}$ & $2.15 * *$ \\
\hline Columns within (L) & 6 & 1.30 & 2.20 & 0.068 & 2.46 & 0.133 & 0.107 \\
\hline Rows within (L) & 6 & 2.11* & 3.20 & 0.033 & 1.03 & 0.108 & 0.077 \\
\hline Genotypes within (L) & 6 & 1.66 & 2.60 & 0.100 & 3.88 & $1.93 * *$ & $0.680 * *$ \\
\hline Genotypes (G) & 3 & 1.65 & 3.57 & 0.127 & 4.06 & $3.43 * *$ & $1.35 * *$ \\
\hline G $\times \mathbf{L}$ & 3 & 1.66 & 1.63 & 0.073 & 3.70 & $0.440 *$ & 0.010 \\
\hline Experimental error & 12 & \multirow[t]{2}{*}{0.697} & \multirow[t]{2}{*}{1.33} & \multirow[t]{2}{*}{0.063} & \multirow[t]{2}{*}{1.81} & \multirow[t]{2}{*}{0.113} & \multirow[t]{2}{*}{0.089} \\
\hline Total & 31 & & & & & & \\
\hline
\end{tabular}

*, ** Significant at 0.05 and 0.01 levels, respectively. 
Table (9): Means of yield and its components for combined latin square.

\begin{tabular}{|c|c|c|c|c|c|c|}
\hline \multicolumn{7}{|c|}{ Delta } \\
\hline Genotypes & $\begin{array}{c}\text { S. Y. } \\
\text { (k/fed.) }\end{array}$ & $\begin{array}{l}\text { L. Y. } \\
\text { (k/fed.) }\end{array}$ & $\begin{array}{c}\text { B. W. } \\
\text { (g) }\end{array}$ & $\mathbf{S} / \mathbf{B}$ & $\begin{array}{r}\text { S. I. } \\
(\mathrm{g})\end{array}$ & $\begin{array}{r}\text { L. I. } \\
\text { (g) }\end{array}$ \\
\hline G86 & 10.86 & 13.73 & 3.10 & 17.93 & 10.36 & 6.96 \\
\hline G89 x G86 & 11.00 & 13.55 & 2.82 & 17.17 & 10.00 & 6.44 \\
\hline G75 x Sea & 11.89 & 14.19 & 3.03 & 18.50 & 10.16 & 6.19 \\
\hline 10229 x G86 & 12.46 & 16.23 & 3.17 & 16.52 & 11.28 & 7.96 \\
\hline L.S.D. & 0.58 & 0.84 & 0.15 & 0.90 & 0.26 & 0.21 \\
\hline \multicolumn{7}{|c|}{ Upper Egypt } \\
\hline Genotypes & $\begin{array}{c}\text { S. Y. } \\
\text { (k/fed.) }\end{array}$ & $\begin{array}{c}\text { L. Y. } \\
\text { (k/fed.) }\end{array}$ & $\begin{array}{c}\text { B. W. } \\
(\mathrm{g})\end{array}$ & $\mathbf{S} / \mathbf{B}$ & $\begin{array}{r}\text { S. I. } \\
\text { (g) }\end{array}$ & $\begin{array}{r}\text { L. I. } \\
\text { (g) }\end{array}$ \\
\hline G80 & 9.47 & 12.01 & 2.93 & 17.16 & 10.21 & 6.91 \\
\hline G90 & 9.32 & 11.45 & 2.71 & 16.79 & 9.93 & 6.36 \\
\hline$(G 83 \times(G 75 \times 5844)) \times$ G80 & 10.29 & 13.04 & 2.68 & 16.35 & 9.91 & 6.60 \\
\hline G90 x Australian & 9.37 & 11.94 & 2.65 & 18.03 & 8.74 & 5.94 \\
\hline L.S.D. & -- & -- & -- & -- & 0.37 & 0.33 \\
\hline
\end{tabular}

-- : Not significant at 0.05 level.

Table (10): Mean squares of yield and its components for multiple latin square.

\begin{tabular}{|c|c|c|c|c|c|c|c|}
\hline Source of variation & df & $\begin{array}{c}\text { S. Y. } \\
\text { (k/fed.) }\end{array}$ & $\begin{array}{c}\text { L. Y. } \\
\text { (k/fed.) }\end{array}$ & $\begin{array}{c}\text { B. W. } \\
(\mathrm{g})\end{array}$ & S / B & $\begin{array}{r}\text { S. I. } \\
\text { (g) }\end{array}$ & $\begin{array}{r}\text { L. I. } \\
\text { (g) }\end{array}$ \\
\hline Columns & 7 & $2.80 *$ & $4.31 *$ & 0.118* & 7.74** & 0.586* & 0.102 \\
\hline Rows & 7 & $2.62 *$ & 2.71 & $0.219 * *$ & 0.970 & $2.32 * *$ & $0.329 * *$ \\
\hline Genotypes & 7 & $11.25 * *$ & $18.93 * *$ & $0.325 * *$ & $4.76 *$ & $3.88 * *$ & $3.13 * *$ \\
\hline Cultivars & 2 & $5.75 * *$ & $11.21 * *$ & $\mathbf{0 . 3 0 7} * *$ & 2.70 & 0.395 & $0.887 * *$ \\
\hline Varieties & 4 & $12.12 * *$ & $20.26 * *$ & $0.408 * *$ & $6.98 * *$ & $6.50 * *$ & $4.98 * *$ \\
\hline Cultivars vs & 1 & $18.79 * *$ & $29.06 * *$ & 0.030 & 0.006 & 0.335 & 0.219 \\
\hline Experimental error & 42 & 1.08 & 1.68 & 0.047 & 1.57 & 0.193 & 0.090 \\
\hline Total & 63 & & & & & & \\
\hline
\end{tabular}

*,** Significant at 0.05 and 0.01 levels, respectively.

Table (11): Means of yield and its components for multiple latin square.

\begin{tabular}{|c|c|c|c|c|c|c|}
\hline Genotypes & $\begin{array}{c}\text { S. Y. } \\
\text { (k/fed.) }\end{array}$ & $\begin{array}{l}\text { L. Y. } \\
\text { (k/fed.) }\end{array}$ & $\begin{array}{c}\text { B. W. } \\
\text { (g) }\end{array}$ & S / B & $\begin{array}{r}\text { S. I. } \\
\text { (g) }\end{array}$ & $\begin{array}{r}\text { L. I. } \\
\text { (g) }\end{array}$ \\
\hline Cultivars & 9.88 & 12.40 & 2.91 & 17.29 & 10.17 & 6.74 \\
\hline G86 & 10.86 & 13.73 & 3.10 & 17.93 & 10.36 & 6.96 \\
\hline G80 & 9.47 & 12.01 & 2.93 & 17.16 & 10.21 & 6.91 \\
\hline G90 & 9.32 & 11.45 & 2.71 & 16.79 & 9.93 & 6.36 \\
\hline Varieties & 11.00 & 13.79 & 2.87 & 17.31 & 10.02 & 6.63 \\
\hline G89 x G86 & 11.00 & 13.55 & 2.82 & 17.17 & 10.00 & 6.44 \\
\hline G75 x Sea & 11.89 & 14.19 & 3.03 & 18.50 & 10.16 & 6.19 \\
\hline 10229 x G86 & 12.46 & 16.23 & 3.17 & 16.52 & 11.28 & 7.96 \\
\hline$(G 83 \times(G 75 \times 5844)) \times G 80$ & 10.29 & 13.04 & 2.68 & 16.35 & 9.91 & 6.60 \\
\hline G90 x Australian & 9.37 & 11.94 & 2.65 & 18.03 & 8.74 & 5.94 \\
\hline Cultivars vs. Varieties & 1.12 & 1.39 & 0.04 & 0.02 & 0.15 & 0.11 \\
\hline L.S.D. & 1.05 & 1.31 & 0.22 & 1.27 & 0.44 & 0.30 \\
\hline
\end{tabular}

of analysis of variance showed that variance among varieties was bigger than among cultivars for yield and its components except for boll weight (Table 10).
3.4. Comparisons between traditional combined and multiple latin square design

Multiple analysis can easily calculate the variance among genotypes which were grown in 
different separated zones, such as the Delta and Upper Egypt in one step as shown in (Table 10), while combined analysis can not do that these results revealed that multiple surpassed combined due to it made two directions of the analysis (different groups of genotypes and different locations as shown in (Table 10), while combined analysis made one direction of analysis (one group of genotypes in different location) as represented in (Table 8).

Multiple used only one value of L.S.D. to compare within two groups of genotypes as shown in (Table 11), while combined used two values of L.S.D. (one for each group) as rerealed in (Table 9). In addition, multiple does not need to calculate homogeneity test of variances (Bartlett test) before starting the analysis.

Multiple gave information about the level of production for both cultivars and new varieties within the two groups, while combined gave the same details within only one group.

\section{REFERENCES}

Abou Tour H. B., Seyam S. M. and Abd El Rahman L. M. (1996). Analytical study on the economic characters of new and commercial Egyptian cotton. Egypt. J. Agric. Res., 74 (3) : 781-791.

Arafa A. S., and Nour O. D. (2011). Evaluation of fiber properties of some Egyptian cotton genotypes under different environments using geometric method. Journal of American Sciences 7 (10) : $416-421$.

Bailey N. T. (1994). Statistical Methods in Biology. Third Edit. Cambridge University Press, Cambridge, England.

Cochran W.G and Cox G. W. (1950). Experimental Designs. John Wiley and Sons, New York., U.S.A.

El Oraby S.H. (1998). Studies on yield of some Egyptian cotton varieties under different environments. M.Sc. Thesis, Kafr El Sheikh, Tanta Univ., Egypt.
Federer W. T. ( 1955 ). Experimental Design. Theory and Application. The MacMilan Company New York, U.S.A.

Fowler J., Cohen L. and Jarvis P. (1998). Practical statistics for field biology. Second Edit, John Wiley and Sons, New York, U.S.A.

Gomez K. A. and Gomez A. A. (1984). Statistical Procedures for Agricultural Research. John Wiley and Sons, New York, U.S.A.

Idris H.A. (2006). Classification of environmental and locational effects on some Egyptian cotton genotypes by using two steps of latin square design and cluster analysis. Bull. Fac. Agric., Cairo Univ., 57 (1): 53-65.

Idris H.A. (2008). Evaluation of some Egyptian cotton genotypes in the first and the second picks by latin square design with a combined analysis. Bull. Fac. Agric., Cairo Univ., 59 (1): 13-23.

Idris H. A. and Abou Tour H. B. (2007). Estimation of the variance of some Egypian cotton genotypes in the Delta and Upper Egypt using different approaches of combined analysis. Bull. Fac. Agric., Cairo Univ., 58 (3): $179-187$.

Little T.M. and Hills F. J. (1978). Agricultural Experimentation Design and Analysis. John Wiley and Sons, New York., U.S.A.

Mcpherson G. (2001). Applying and Interpreting Statistics A. Comprehensive Guide. Second Edit, Springer Verlag New York, Inc. U.S.A.

Roger G. P. (1994). Agricultural Field Experiments Design and Analysis. Marcel Dekker, Inc. New York, U.S.A.

Sing P. and Narayanan S. S. (2000). Biometrical Techniques in Plant Breeding. Second Edit., Ludhiana, New Delhi, India.

Snedecor G W. and Cochran W. G. (1967). Statistical methods. Iowa State. Univ. Press, Ames, Iowa, U. S. A.

Steel R. G. and Torrie J. H. (1980). Principles and Procedures of Statistics. Second Edit., McGraw. Hill. Book Co. New York, U.S.A. 


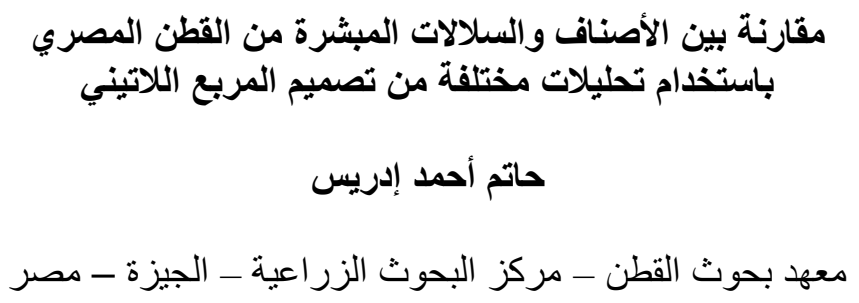

ملخص

تم تقييم المحصول ومكوناته و الصفات التكنولوجية لأربع تر اكيب ور اثية من القطن المصري طويلة التيلة ثلاثة منها

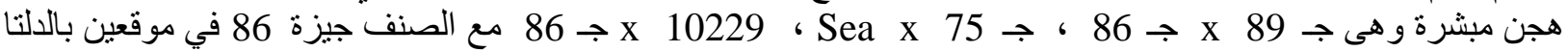

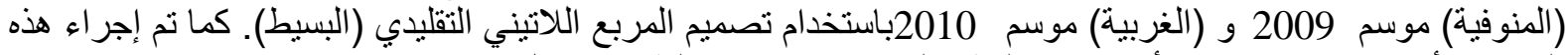

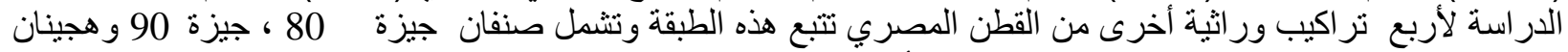

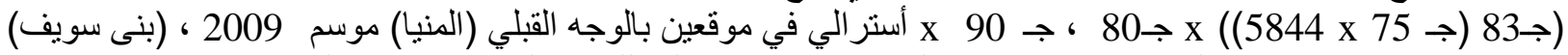

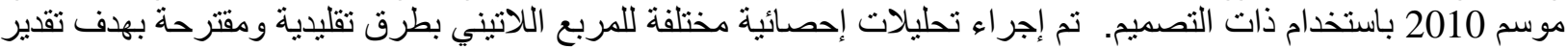
التباين بين التر اكيب الور اثية و المقارنة بين الأصناف المنزر عة حاليا والهين الهن المبشرة التي لم يتم اعتمادها كأصناف.

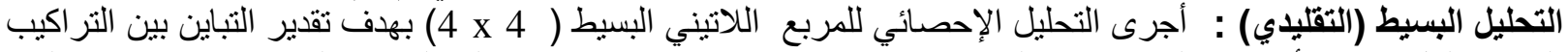

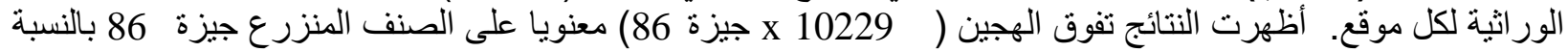

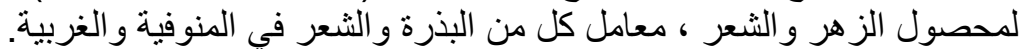

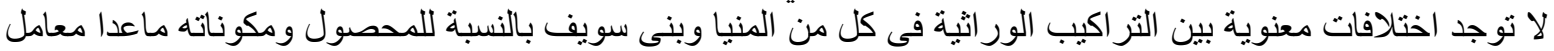

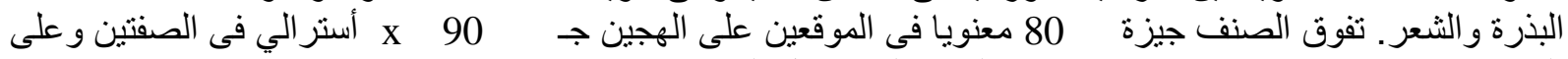

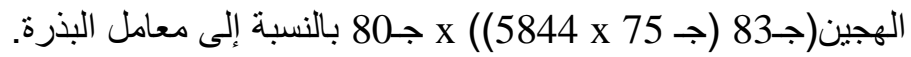

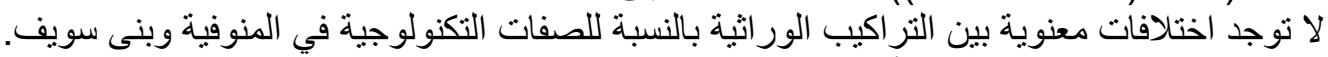

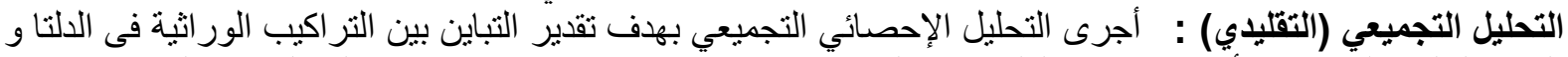

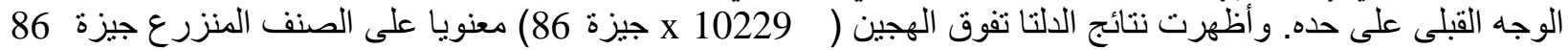

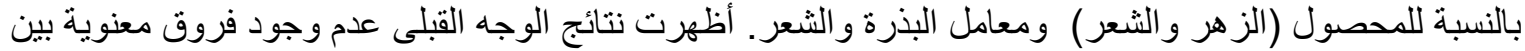

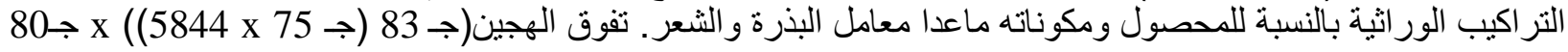

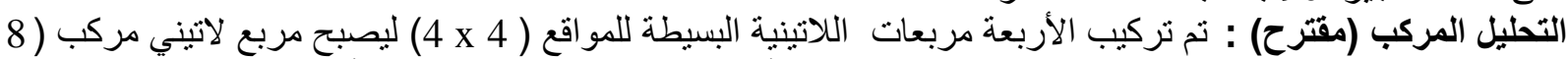

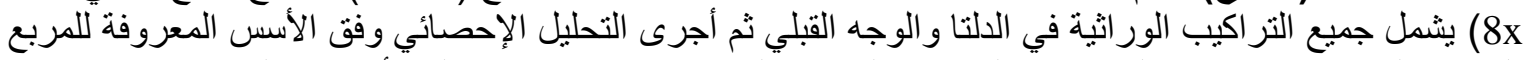

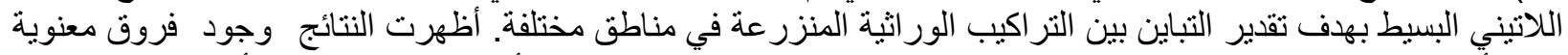

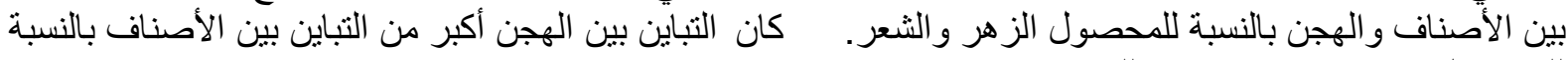

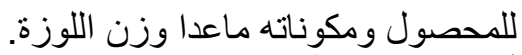

أظهرت الدراسة : تفوق التحليل المركب على على التجميعي التقليدي بإمكانية التحليل في اتجاهين (مجموعنين من التر اكيب الور اثية كل مجموعة تم زر اعتها في مناطق مختلفة عن الأخرى) بينما بعتمد التحليل التجميعي التقليدي على التحلي التحليل في اتجاه و احد (مجمو عة من التر اكيب الور اثية تم زر اعنه اعتها في مناطق مختلفة). ويستفاد من هذه الدر استة في بر امج التقييم الإقليمي للقطن. 